\title{
Physical Quality of an Oxisol in Different Agricultural Systems in Brazilian Cerrado
}

\author{
Diego dos Santos Pereira ${ }^{1}$, Rafael Montanari ${ }^{1}$, Christtiane Fernandes Oliveira ${ }^{1}$, Jean Carlos de Almeida Ramos ${ }^{1}$, \\ Alan Rodrigo Panosso ${ }^{1}$, Zigomar Menezes de Souza ${ }^{2} \&$ Antonio Paz González ${ }^{3}$ \\ ${ }^{1}$ Department of Plant Health, Rural Engineering, and Soils, College of Engineering, Sao Paulo State University, \\ Ilha Solteira, SP, Brazil \\ ${ }^{2}$ Department of Soil and Water, University of Campinas, Campinas, SP, Brazil \\ ${ }^{3}$ Department of Soil Science, University of a Coruña, Coruña, Espanha, Spain \\ Correspondence: Diego dos Santos Pereira, Department of Plant Health, Rural Engineering, and Soils, College \\ of Engineering, Sao Paulo State University, Ilha Solteira, State of Sao Paulo, Brazil. Tel: 55-(18)-9811-99561. \\ E-mail: diegol_360@hotmail.com.br
}

Received: April 11, 2018

doi:10.5539/jas.v10n7p46

\author{
Accepted: May 13, $2018 \quad$ Online Published: June 15, 2018 \\ URL: https://doi.org/10.5539/jas.v10n7p46
}

\begin{abstract}
The soil physical quality is a way of evaluating the current condition of forest plantations that is growing in the southeast region of Mato Grosso do Sul State. In this sense, this work aimed to evaluate the impact of the forest plantations on the physical quality of an Oxisol (Haplic Acrustox) in Cerrado. The experiment was conducted in the Experimental area of the Teaching and Research Farm, of the Engineering college of Ilha Solteira (UNESP), located in the city of Selvíria-MS, situated in the conditions of the Brazilian Cerrado. The soil samples were collected at depths of $0.00-0.10 ; 0.10-0.20 ; 0.20-0.30$ and $0.30-0.40 \mathrm{~m}$ in three areas cultivated for 30 years: area (1) Pine forest (Pinus caribaea var. hondurensis); (2) Eucalyptus forest (Eucalyptus camaldulensis); (3) Reforested ciliary forest, being used a completely randomized design, with 25 replications and 3 treatments. The analyzed attributes of the soil was: macroporosity (Ma), microporosity (Mi), total porosity (TP), bulk density (BD), real particle (RP), soil resistance to penetration (PR), gravimetric moisture (GM), volumetric moisture (VM) and sand, silt and clay contents. The three evaluated areas presented macroporosity below the critical limit $\left(0.100 \mathrm{~m}^{3} \mathrm{~m}^{-3}\right)$, thereby impairing the root development. The three evaluated areas affected the physical quality of the soil. Being the physical attributes that most influenced in the reduction of the soil physical quality was the bulk density, total porosity, microporosity, macroporosity and soil resistance to penetration.
\end{abstract}

Keywords: Eucalyptus camaldulensis, reforested ciliary forest, soil structure, Pinus caribaea

\section{Introduction}

Brazil is among the ten countries with the largest forest areas in the world. In 2015, the country had an area of 493538 thousand ha, representing 12\% of the global forest area (Macdiken, 2015). With 7.84 million ha of reforestation, the Brazilian sector of planted trees is responsible for $91 \%$ of wood produced for industrial purposes and $6.2 \%$ of the Industrial GDP in the Country and is one of the segments with the highest potential of contributing to building a green economy (Indústria Brasileira de Árvores, 2017).

The perspective of increasing the world demand for cellulose and for certified wood and the strategic use of forests for carbon sequestration, in the ambit of clean development mechanisms, make increase the demand for technologies directed to sustainable forest production and for studies on the impacts of this activity in the environment, notably the soils (Silva et al., 2009).

Currently, the challenges are increasing to produce food, fiber, energy, logger and non-logger products in a manner compatible with the availability of natural resources, mainly soil and water. Therefore, is increased the need to spread the concept of sustainable agriculture, seeking at the preservation and the quality of these resources (Cordeiro et al., 2015).

The excessive exploitation of natural resources with the gradual replacement of the original vegetation by cultivated areas have caused changes in the soil, making it poorer and unable to supply the need of plants for their development (Silva et al., 2012). Cerrado is the Brazilian biome that has suffered the highest rates of 
deforestation, due to the process of expansion of the country's agricultural frontiers. Part of this is due to the edaphoclimatic and physiographic conditions, favorable to the establishment of eucalyptus and pine plantations in the 1970s and 1980s, the reforestation with these species had great expansion in the Cerrado region (Juvenal \& Mattos, 2002).

In this sense, the evaluation of the physical quality of the soil (PQS) becomes an important tool to evaluate the changes caused by the use of exotic forest species in Cerrado soils, such as the studies of (Bonini et al., 2015) that monitored the recovery of the structure of a degraded Oxisol in Mato Grosso do Sul, Cerrado, using sewage sludge with use of the species eucalyptus (Eucalyptus citriodora) and brachiaria (Brachiaria decumbens), verifying for the native vegetation (NV) and eucalyptus forest (EF) in the layers of $0-0.10 ; 0.10-0.20 ; 0.20-0.40$ $\mathrm{m}$, the following macroporosity values respectively, of (VN; $0.19 ; 0.13$ and $\left.0.16 \mathrm{~m}^{3} \mathrm{~m}^{-3}\right)$ and of $(\mathrm{FE} ; 0.13 ; 0.05$ and $0.04 \mathrm{~m}^{3} \mathrm{~m}^{-3}$ ).

The understanding of properties and processes related to the capacity of the soil to effectively condition the environmental or ecosystem services essential to ecosystem health is PQS (Millennium Ecosystem Assessment, 2005). This survey was carried out through physical indicators of soil quality, responsible for the evaluation of its structure. Thus, this study aimed to evaluate the impact of forest plantations in the physical quality of an Oxisol (Haplic Acrustox) of the low altitude Cerrado.

\section{Method}

\subsection{Field Sites and Material Description}

The experiment was conducted in three areas where cerrado was a natural vegetation: the first under a eucalyptus (Eucalyptus camaldulensis) settlement, the second under a reforested ciliary forest with native species, and the third with pine reforestation (Pinus caribaea var. hondurensis) implanted 30 years ago. The evaluations were carried out in the agricultural year 2016/2017, in the city of Selvíria (MS), in the latitude of $20^{\circ} 22^{\prime} \mathrm{S}$ and longitude of $51^{\circ} 22^{\prime} \mathrm{W}$, near the Paraná River basin, having $335 \mathrm{~m}$ altitude.

According to the Koppen-Geiger classification, the climate of the region is Aw, characterized as humid tropical, with the rainy season in the summer, and dry in the winter, with average annual precipitation of $1.300 \mathrm{~mm}$ and an average temperature of $23.7^{\circ} \mathrm{C}$. The weather conditions during the experiment conduction are exposed in Figure 1. The soil of the experimental area was classified according to the standards of Empresa Brasileira de Pesquisa Agropecuária classification (2014) is an Oxisol (Latossolo Vermelho/Haplic Acrustox).

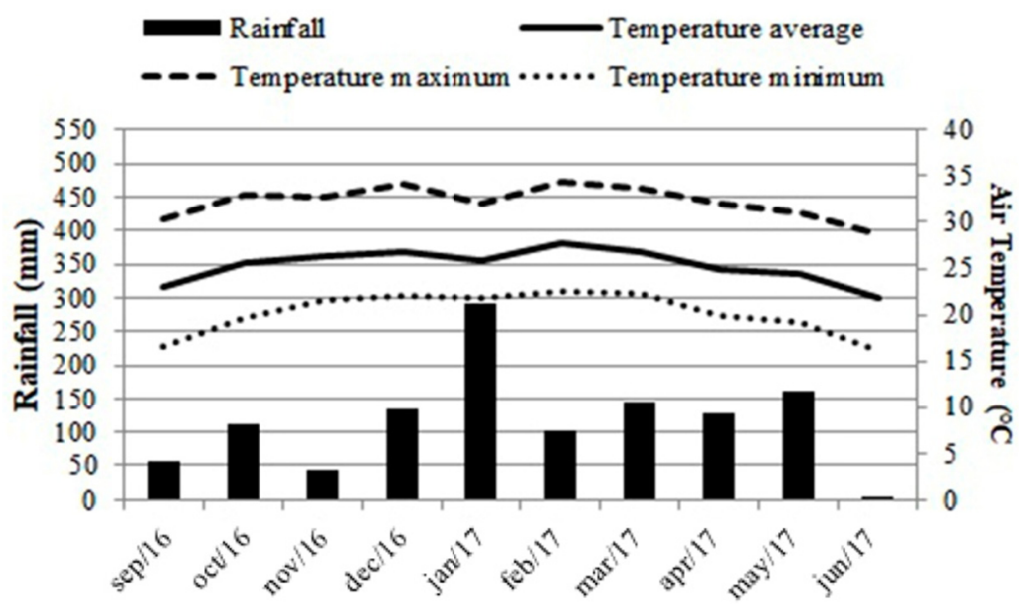

Figure 1. Rainfall $(\mathrm{mm})$ and temperature $\left({ }^{\circ} \mathrm{C}\right)$ maximum, average and minimum, during the evaluation period of the experiment in an Oxisol (Haplic Acrustox) under cultivation Eucalyptus camaldulensis, ciliary forest and

Pinus caribaea var. hondurensis

The natural vegetation of the region is the Cerrado, being that in the experimental area, was carried out deforestation in May 1978, for the planting of annual cultures, with conventional sowing (heavy and light grid). In 1986, part of the area of annual cultures was replaced by a population of Eucalyptus camaldulensis, under a space of $4 \times 4 \mathrm{~m}$, occupying an area of three hectares. Another four hectares were used for planting a population of Pinus caribaea var. hondurensis under a space of $3 \times 3 \mathrm{~m}$. 
Part of the area was made up of species of: Albizia lebeck, Chorisia speciosa, Cydonia oblonga, Enterolobium contortisiliguun, Eugenia jambolaria, Ficus clusiaefolia, Holocalyx glaziovii, Hovenia dulcis, Jacaranda semisenata, Koelrenteria paniculata, Moquilea fomentosa, Morus nigra, Myroxylon balsamun, Peltophorum dubium, Psidium guajava, Pterocarpus quercinus, Pelophorum vogelianum, Spondias venulosa, Tabebuia chrysotricha, Tabebuia impetiginosa and Tabebuia odontodiscus. Distributed in a randomized way, under a space of $3 \times 2 \mathrm{~m}$, being denominated as reforested ciliary forest.

\subsection{Experimental Design and Analytical Procedures}

The experimental design used was a completely randomized, with 25 replicates and 3 treatments, which corresponded to three different areas: eucalyptus (Eucalyptus camaldulensis), pine (Pinus caribaea var. Hondurensis) and ciliary forest reforested, and four depths $0.00-0.10 ; 0.10-0.20 ; 0.20-0.30$ and $0.30-0.40 \mathrm{~m}$.

The soil samples were collected on November 8, 2016 and May 13, 2017, around the sampling points. On both dates, soil samples were collected, deformed and undisturbed, and at the same time, the test was performed by means of an impact penetrometer to obtain the data used to calculate the soil resistance to penetration (PR, MPa). The deformed soil samples, removed by means of a canecoid, were stored in hermetically sealed containers and were subsequently used for laboratory determination of gravimetric moisture $\left(\mathrm{GM}, \mathrm{kg} \mathrm{kg}^{-1}\right)$. Another part of the soil samples were stored in plastic bags for determination of real particle (RP, $\mathrm{kg} \mathrm{dm}^{-3}$ ), and soil granulometry (sand, silt and clay, $\mathrm{g} \mathrm{kg}^{-1}$ ). The soil samples, in preserved structure, were used to determine the macroporosity $\left(\mathrm{Ma}, \mathrm{m}^{3} \mathrm{~m}^{-3}\right)$, microporosity $\left(\mathrm{Mi}, \mathrm{m}^{3} \mathrm{~m}^{-3}\right)$ and the bulk density $\left(\mathrm{BD}, \mathrm{kg} \mathrm{dm}^{-3}\right)$.

The granulometric analysis of the soil was performed by the pipette method, using $0.1 \mathrm{~N} \mathrm{NaOH}$ solution as chemical dispersant and shaking for 16 hours at an orbital table. The clay fraction was separated by sedimentation, the sand, by sieving and the silt, calculated by difference (Embrapa, 2017).

The bulk density (BD) was determined by the volumetric ring method, using Equation 1:

$$
B D\left(\mathrm{~kg} \mathrm{dm}^{-3}\right)=M d / V r
$$

Where, Md corresponds to the mass of dry soil in the oven $(\mathrm{kg})$; and $\mathrm{Vr}$, to the volume of the ring $\left(\mathrm{dm}^{-3}\right)$.

The gravimetric moisture (GM) was determined by the thermogravimetric method, using an analytical balance with a precision $\pm 0.005 \mathrm{~g}$, by the Equation 2 (Kiehl, 1979).

$$
G M\left(\mathrm{~kg} \mathrm{~kg}^{-1}\right)=(M m-M d) / M d
$$

Where, Md corresponds to the mass of dry soil in oven $(\mathrm{kg})$, and Mm corresponds to the mass of moist soil $(\mathrm{kg})$.

The soil samples, in preserved structure, were saturated by means of gradual elevation of a water slide until reaching about $2 / 3$ of the ring height, after which they were taken to the suction table for $24 \mathrm{~h}$ at the tension of 6 $\mathrm{kPa}$, and then dried in an oven at $105^{\circ} \mathrm{C}$ for $24 \mathrm{~h}$. At each step, the samples were weighed, and the data were used in Equations 3, 4 and 5 to determine $\mathrm{Ma}, \mathrm{Mi}, \mathrm{TPd}$ :

$$
\begin{gathered}
M a\left(\mathrm{~m}^{3} \mathrm{~m}^{-3}\right)=(S t s-M s) / V r \\
M i\left(\mathrm{~m}^{3} \mathrm{~m}^{-3}\right)=(M s-D s) / V r \\
T P d\left(\mathrm{~m}^{3} \mathrm{~m}^{-3}\right)=(M i+M a)
\end{gathered}
$$

Where, Sts corresponds to saturated soil condition; Ms, to the moist soil with water content corresponding to the tension of $6 \mathrm{kPa}$ in the tension table; Ds, to the dry soil in the oven; and $\mathrm{Vr}$, to the volume of the ring.

The volumetric moisture (VM) and the total soil porosity calculated (TPc) were measured according to the Equations 6 and 7 (Libardi, 2005).

$$
\begin{aligned}
V M\left(\mathrm{~m}^{3} \mathrm{~m}^{-3}\right) & =G M \times B D \\
\operatorname{TPC}\left(\mathrm{m}^{3} \mathrm{~m}^{-3}\right) & =1-(B D / R P)
\end{aligned}
$$

Where, VM is the volumetric moisture $\left(\mathrm{m}^{3} \mathrm{~m}^{-3}\right), \mathrm{GM}$ is the gravimetric moisture $\left(\mathrm{kg} \mathrm{kg}^{-1}\right), \mathrm{BD}$ is the bulk density $\left(\mathrm{kg} \mathrm{dm}^{-3}\right)$, and RP is the real particle $\left(\mathrm{kg} \mathrm{dm}^{-3}\right)$. For the GM were used soil samples with deformed structure, collected with a mug.

The method employed to determine the soil physical attributes was the one recommended by Embrapa (2017). Using an auger mug, deformed soil samples were removed to determine the GM, RP and soil granulometry.

The gravimetric moisture (GM) was determined by the thermogravimetric method, using an analytical balance with an accuracy of $\pm 0.005 \mathrm{~g}$, by Equation 8 (Kiehl, 1979). 


$$
G M\left(\mathrm{~kg} \mathrm{~kg}^{-1}\right)=(M m-M d) / M d
$$

Where, Md corresponds to the mass of dry soil in the oven $(\mathrm{kg})$; Mm corresponds to the mass of moist soil (kg).

The real particle (RP) was determined from $20 \mathrm{~g}$ of soil dried in oven for a period of $12 \mathrm{~h}$ at $105^{\circ} \mathrm{C}$, deposited in a volumetric flask $(50 \mathrm{~mL})$, adding ethyl alcohol to $20 \mathrm{~g}$ of soil until the volume of the flask is complete, being the RP being calculated using Equation 9:

$$
R P\left(\mathrm{~kg} \mathrm{dm}^{-3}\right)=S d /(50-V a)
$$

Where, $\mathrm{Sd}$ is the $20 \mathrm{~g}$ of soil dried, Va is the volume of alcohol used to complete the flask with the soil sample, in $\mathrm{mL}$. BD was determined by the volumetric ring method.

The soil resistance to penetration (PR) data was obtained through of an impact penetrometer. The expression used for the calculation was that of (Stolf et al., 2014), represented by the Equation 10:

$$
P R=\{5.581+6.891 \times[N /(A-B) \times 10] \times 0.0981\}
$$

Where, $\mathrm{PR}$ is the soil resistance to penetration $(\mathrm{MPa}) ; \mathrm{N}$ is the number of impacts made with the hammer of the penetrometer to obtain the reading, and $\mathrm{B}$ and $\mathrm{A}$ are the readings before and after the impacts $(\mathrm{cm})$.

The data from the areas of eucalyptus (E. camaldulensis), reforested ciliary forest and pinus (Pinus caribaea var. Hondurensis) were compared and submitted to variance analysis. When the F test was significant, the averages were compared by the Tukey test at the $1 \%$ and 5\% probability level, using software R (R Core Team, 2014).

\section{Results}

\subsection{Statistical Analysis Among the Attributes of the Areas Under Eucalyptus, Ciliary Forest and Pine Cultures}

The granulometric attributes presented difference at $1 \%$ of the probability, by the $\mathrm{F}$ test, between the studied areas, and was verified dominance in the sand fraction, in all depths of the evaluated areas (Table 1). The area with ciliary forest presented the lowest sand contents (459 to $542 \mathrm{~g} \mathrm{~kg}^{-1}$ ) for the four depths, and higher silt (65 to $68 \mathrm{~g} \mathrm{~kg}^{-1}$ ) and clay (393 to $473 \mathrm{~g} \mathrm{~kg}^{-1}$ ) contents. The results corroborated those of Cavenage et al. (1999), studying the physical attributes of an Oxisol, in the same experimental area and evaluated depths and observed lower sand values $\left(506 \mathrm{~g} \mathrm{~kg}^{-1}\right)$ and higher silt $\left(65 \mathrm{~g} \mathrm{~kg}^{-1}\right)$ and clay $\left(427 \mathrm{~g} \mathrm{~kg}^{-1}\right)$ contents for area with ciliary forest, comparing to areas of eucalyptus and pine. The variation of the clay content in the ciliary forest is related to the position of the area in the toposequence (Foothill), having influenced in the process of drainage, erosion, and deposition of the material of origin in this region since in the evaluated layers the primary particle content was similar.

\begin{tabular}{|c|c|c|c|c|c|}
\hline \multirow{2}{*}{ Depths } & \multicolumn{3}{|c|}{ Average } & \multirow{2}{*}{ CV $(\%)$} & \multirow{2}{*}{ Calc. F } \\
\hline & Eucalyptus & Ciliary Forest & Pine & & \\
\hline \multicolumn{6}{|l|}{ Sand $\left(g \mathrm{~kg}^{-1}\right)$} \\
\hline $0.00-0.10 \mathrm{~m}$ & $611 \mathrm{~b}$ & $542 \mathrm{c}$ & $648 \mathrm{a}$ & 5.93 & $57.029^{* *}$ \\
\hline $0.10-0.20 \mathrm{~m}$ & $599 \mathrm{~b}$ & $516 \mathrm{c}$ & $624 \mathrm{a}$ & 6.07 & $64.183^{* *}$ \\
\hline $0.20-0.30 \mathrm{~m}$ & $579 \mathrm{a}$ & $485 \mathrm{~b}$ & $593 \mathrm{a}$ & 6.06 & $76.780^{* *}$ \\
\hline $0.30-0.40 \mathrm{~m}$ & $559 \mathrm{a}$ & $459 \mathrm{~b}$ & $576 \mathrm{a}$ & 6.41 & $86.809^{* *}$ \\
\hline \multicolumn{6}{|l|}{ Silt $\left(g \mathrm{~kg}^{-1}\right)$} \\
\hline $0.00-0.10 \mathrm{~m}$ & $57 \mathrm{a}$ & $65 \mathrm{a}$ & $26 \mathrm{~b}$ & 28.72 & $53.472^{* *}$ \\
\hline $0.10-0.20 \mathrm{~m}$ & $56 \mathrm{~b}$ & $67 \mathrm{a}$ & $33 \mathrm{c}$ & 27.95 & $34.043^{* *}$ \\
\hline $0.20-0.30 \mathrm{~m}$ & $56 \mathrm{~b}$ & $68 \mathrm{a}$ & $34 \mathrm{c}$ & 26.86 & $35.861^{* *}$ \\
\hline $0.30-0.40 \mathrm{~m}$ & $57 \mathrm{~b}$ & $68 \mathrm{a}$ & $35 \mathrm{c}$ & 29.31 & $30.073^{* *}$ \\
\hline \multicolumn{6}{|l|}{ Clay $\left(\mathrm{g} \mathrm{kg}^{-1}\right)$} \\
\hline $0.00-0.10 \mathrm{~m}$ & $332 \mathrm{~b}$ & $393 \mathrm{a}$ & $326 \mathrm{~b}$ & 10.65 & $24.097^{* *}$ \\
\hline $0.10-0.20 \mathrm{~m}$ & $345 \mathrm{~b}$ & $417 \mathrm{a}$ & $343 \mathrm{~b}$ & 9,87 & $34,158^{* *}$ \\
\hline $0.20-0.30 \mathrm{~m}$ & $365 \mathrm{~b}$ & $447 \mathrm{a}$ & $373 b$ & 8,03 & $50,769^{* *}$ \\
\hline $0.30-0.40 \mathrm{~m}$ & $384 \mathrm{~b}$ & $473 \mathrm{a}$ & $389 \mathrm{~b}$ & 8,03 & $55,595^{* *}$ \\
\hline
\end{tabular}

Table 1. Attributes of an Oxisol (Haplic Acrustox), collected at depths of 0.00-0.10 m; 0.10-0.20 m; 0.20-0.30 m and $0.30-0.40 \mathrm{~m}$; under cultivation of eucalyptus, ciliary forest, and pine

Note. ${ }^{1}$ Averages followed by the same letter in the line do not differ statistically by the Tukey test. * Significant at $5 \%, * *$ Significant at $1 \%$. 
Regarding RP, the areas presented difference, by the F test, at 1 and 5\% probability (Table 2). The ciliary forest presented higher values of RP1 compared to the values of the areas under cultivation of eucalyptus and pine, at $1 \%$ probability, whereas for RP3, the area under ciliary forest presented a value higher than the pine area, with $5 \%$ of probability for the $\mathrm{F}$ test. In relation to RP4, under eucalyptus and ciliary forest, the RP values were higher than the area under pine, with a difference at $1 \%$ probability, by the $\mathrm{F}$ test.

Table 2. Attributes of an Oxisol (Haplic Acrustox), collected at depths of 0.00-0.10 m; 0.10-0.20 m; 0.20-0.30 m and $0.30-0.40 \mathrm{~m}$ under cultivation of eucalyptus, ciliary forest, and pine

\begin{tabular}{|c|c|c|c|c|c|}
\hline \multirow{2}{*}{ Depths } & \multicolumn{3}{|c|}{ Average } & \multirow{2}{*}{ CV (\%) } & \multirow{2}{*}{ Calc. F } \\
\hline & Eucalyptus & Ciliary forest & Pine & & \\
\hline \multicolumn{6}{|l|}{$R P\left(\mathrm{~kg} \mathrm{dm}^{-3}\right)$} \\
\hline $0.00-0.10 \mathrm{~m}$ & $2.524 \mathrm{~b}$ & $2.621 \mathrm{a}$ & $2.568 \mathrm{~b}$ & 2.78 & $11.590^{* *}$ \\
\hline $0.10-0.20 \mathrm{~m}$ & 2.599 & 2.637 & 2.578 & 3.25 & 3.073 \\
\hline $0.20-0.30 \mathrm{~m}$ & $2.618 \mathrm{ab}$ & $2.644 \mathrm{a}$ & $2.598 \mathrm{~b}$ & 2.22 & $3.968^{*}$ \\
\hline $0.30-0.40 \mathrm{~m}$ & $2.645 \mathrm{a}$ & $2.688 \mathrm{a}$ & $2.595 \mathrm{~b}$ & 2.21 & $10.260^{* *}$ \\
\hline \multicolumn{6}{|l|}{$T P c\left(m^{3} m^{-3}\right)$} \\
\hline $0.00-0.10 \mathrm{~m}$ & $0.413 \mathrm{~b}$ & $0.488 \mathrm{a}$ & $0.387 \mathrm{~b}$ & 9.16 & $44.511^{* *}$ \\
\hline $0.10-0.20 \mathrm{~m}$ & $0.414 \mathrm{~b}$ & $0.490 \mathrm{a}$ & $0.424 \mathrm{~b}$ & 6.74 & $47.831^{* *}$ \\
\hline $0.20-0.30 \mathrm{~m}$ & $0.436 \mathrm{~b}$ & $0.480 \mathrm{a}$ & $0.440 \mathrm{~b}$ & 7.51 & $12.388^{* *}$ \\
\hline $0.30-0.40 \mathrm{~m}$ & $0.466 \mathrm{~b}$ & $0.507 \mathrm{a}$ & $0.473 \mathrm{~b}$ & 6.43 & $12.333^{* *}$ \\
\hline \multicolumn{6}{|l|}{$\operatorname{TPd}\left(\mathrm{m}^{3} \mathrm{~m}^{-3}\right)$} \\
\hline $0.00-0.10 \mathrm{~m}$ & $0.391 \mathrm{~b}$ & $0.446 \mathrm{a}$ & $0.411 \mathrm{~b}$ & 8.10 & $17.136^{* *}$ \\
\hline $0.10-0.20 \mathrm{~m}$ & $0.411 \mathrm{~b}$ & $0.466 \mathrm{a}$ & $0.432 \mathrm{~b}$ & 9.02 & $12.655^{* *}$ \\
\hline $0.20-0.30 \mathrm{~m}$ & $0.420 \mathrm{~b}$ & $0.454 \mathrm{a}$ & $0.444 \mathrm{a}$ & 7.28 & $7.520^{* *}$ \\
\hline $0.30-0.40 \mathrm{~m}$ & $0.440 \mathrm{~b}$ & $0.472 \mathrm{a}$ & $0.472 \mathrm{a}$ & 6.96 & $8.293^{* *}$ \\
\hline \multicolumn{6}{|l|}{$M a\left(m^{3} m^{-3}\right)$} \\
\hline $0.00-0.10 \mathrm{~m}$ & $0.081 \mathrm{a}$ & $0.054 \mathrm{~b}$ & $0.042 \mathrm{~b}$ & 50.67 & $11.097^{* *}$ \\
\hline $0.10-0.20 \mathrm{~m}$ & $0.080 \mathrm{a}$ & $0.043 \mathrm{~b}$ & $0.035 \mathrm{~b}$ & 73.26 & $9.359^{* *}$ \\
\hline $0.20-0.30 \mathrm{~m}$ & $0.077 \mathrm{a}$ & $0.036 \mathrm{~b}$ & $0.036 \mathrm{~b}$ & 56.74 & $17.231^{* *}$ \\
\hline $0.30-0.40 \mathrm{~m}$ & $0.077 \mathrm{a}$ & $0.031 \mathrm{~b}$ & $0.052 \mathrm{~b}$ & 67.02 & $10.450^{* *}$ \\
\hline \multicolumn{6}{|l|}{$\operatorname{Mi}\left(\mathrm{m}^{3} \mathrm{~m}^{-3}\right)$} \\
\hline $0.00-0.10 \mathrm{~m}$ & $0.310 \mathrm{c}$ & $0.393 \mathrm{a}$ & $0.368 \mathrm{~b}$ & 8.44 & $50.454^{* *}$ \\
\hline $0.10-0.20 \mathrm{~m}$ & $0.331 \mathrm{c}$ & $0.423 \mathrm{a}$ & $0.396 \mathrm{~b}$ & 7.12 & $75.858^{* *}$ \\
\hline $0.20-0.30 \mathrm{~m}$ & $0.343 \mathrm{~b}$ & $0.418 \mathrm{a}$ & $0.408 \mathrm{a}$ & 7.01 & $56.119^{* *}$ \\
\hline $0.30-0.40 \mathrm{~m}$ & $0.362 \mathrm{~b}$ & $0.441 \mathrm{a}$ & $0.422 \mathrm{a}$ & 8.47 & $34.908^{* *}$ \\
\hline
\end{tabular}

Note. $\mathrm{RP}=$ real particle; $\mathrm{TPc}=$ total porosity calculated; $\mathrm{TPd}=$ total porosity determined; $\mathrm{Ma}=$ macroporosity, $\mathrm{Mi}=$ microporosity. ${ }^{1}$ Averages followed by the same letter in the line do not differ statistically by the Tukey test.

* Significant at $5 \%, * *$ Significant at $1 \%$.

Overall, in all three treatments, occurred low amplitude in the RP value, ranging from 2.524 to $2.688 \mathrm{~kg} \mathrm{dm}^{-3}$ (Table 2). In the soils of the region where the work was developed, have as predominant minerals, kaolinite, and quartz, besides the Fe oxides (hematite and magnetite), these last, contribute to the increase of RP. While OM, with RP around $1.200 \mathrm{~kg} \mathrm{dm}^{-3}$, contributes to its lowering. This combination of minerals and OM, generate soils with RP in the order of 2.600 to $2.700 \mathrm{~kg} \mathrm{dm}^{-3}$ (van Lier, 2010). In association with this information, the obtained data in the three evaluated areas showed the presence of particles of the same mineral nature, in the three evaluated areas.

When the F-test for TPc was applied, the TPc values of the riparian forest showed differences at $1 \%$ probability, with higher values for TPc1, TPc2, TPc3 and TPc4, ranging from 0.480 to $0,507 \mathrm{~m}^{3} \mathrm{~m}^{-3}$, compared to eucalyptus $\left(0.413\right.$ to $\left.0.466 \mathrm{~m}^{3} \mathrm{~m}^{-3}\right)$ and pine $\left(0.387\right.$ to $\left.0.473 \mathrm{~m}^{3} \mathrm{~m}^{-3}\right)$ areas (Table 2). Similar results were observed by Marques et al. (2012), which found values of TPc ranging from 0.480 to $0.550 \mathrm{~m}^{3} \mathrm{~m}^{-3}$, in the depth of $0.00-0.40$ $\mathrm{m}$, in an Oxisol in an area under forest in Amazon. The higher TPc values of the ciliary forest were related to the 
variety of vegetal species that contribute to the accumulation of vegetal material in the soil, changing the relative proportion of mineral and organic material, reducing the RP and increasing the TPc.

Regarding TPd, it presented differences between the averages by the $\mathrm{F}$ test at $1 \%$ probability (Table 2 ). Among the evaluated areas, TPd1 and TPd2, with 0.446 and $0.466 \mathrm{~m}^{3} \mathrm{~m}^{-3}$ in the ciliary forest area were higher to TPd1 and TPd2 of the eucalyptus area with 0.391 and $0.411 \mathrm{~m}^{3} \mathrm{~m}^{-3}$ and the area under pine cultivation with 0.411 and $0.432 \mathrm{~m}^{3} \mathrm{~m}^{-3}$, respectively. It is possible that the high TPd values in the ciliary forest are related to the presence of a greater number of vegetal species present in the area.

The average values of TPd 3 and TPd4 presented differences by the $\mathrm{F}$ test at $1 \%$ probability, the ciliary forest with 0.454 and $0.472 \mathrm{~m}^{3} \mathrm{~m}^{-3}$ and the area under pine cultivation with 0.444 and $0.472 \mathrm{~m}^{3} \mathrm{~m}^{-3}$, higher compared to TPd 3 and TPd4 of the area under eucalyptus, with average values equal to $0.420 \mathrm{~m}^{3} \mathrm{~m}^{-3}$ and $0.440 \mathrm{~m}^{3} \mathrm{~m}^{-3}$, respectively (Table 2). Possibly the differences are related to the greater amount of Mi present in the areas of ciliary forest and pine. However, is observed by the results presented that the areas of ciliary forest and pine, in terms of pore distribution, were those that presented the most altered, mainly in relation to Ma, well below the critical value of $0.100 \mathrm{~m}^{3} \mathrm{~m}^{-3}$.

The values of Ma differed among the areas, and the highest Ma values were observed in the eucalyptus area, ranging from 0.077 to $0.081 \mathrm{~m} \mathrm{~m}^{3} \mathrm{~m}^{-3}$, while the lowest values were verified in the area of ciliary forest and pine, with variation between 0.031 to $0.054 \mathrm{~m}^{3} \mathrm{~m}^{-3}$ and 0.035 to $0.052 \mathrm{~m}^{3} \mathrm{~m}^{-3}$, respectively. The values of Ma in the eucalyptus area may be related to the high OM contents in the superficial layer from the vegetation cover, contributing to the Ma increase. Different results were found by Melloni et al. (2008), that when evaluated the soil quality under eucalyptus forest, araucaria forest area, pasture area with brachiaria and natural vegetation area, verified that the natural vegetation area presented higher soil $\mathrm{Ma}$ in the depth of $0.00-0.20 \mathrm{~m}$, differing from the other areas.

The values of Ma were below of the recommended by Lima et al. (2017), which is $0.170 \mathrm{~m}^{3} \mathrm{~m}^{-3}$. Also according to the author, most plants develop satisfactorily their root system when the volume of Ma is above $0.100 \mathrm{~m}^{3} \mathrm{~m}^{-3}$. Therefore, the three evaluated areas presented values below the ideal conditions, which suggests that these soils could not present satisfactory aeration conditions for the development of the cultures. However, it should be highlighted that this observation is not valid for all cultures, once there are plants that are tolerant to low levels of soil aeration (Ribeiro et al., 2007).

According to Carter and Kunelius (1986), Ma acts as a very useful index in the evaluation of soil structural modifications, however, it reflects more the soil condition at the time and place of sampling than a final or permanent condition. The adequate values of aeration capacity are dependent on the climatic conditions, therefore, critical values of aeration porosity should be increased under more moist conditions (Thomasson, 1978).

When the $\mathrm{F}$ test for Mi was applied, the ciliary forest presented values higher than the eucalyptus and pine areas, with averages for Mi1 and Mi2 equal to 0.393 and $0.423 \mathrm{~m}^{3} \mathrm{~m}^{-3}$, respectively (Table 2). For Mi3 and Mi4, the average values were, respectively, of 0.418 and $0.441 \mathrm{~m}^{3} \mathrm{~m}^{-3}$ for ciliary forest area, and 0.408 and $0.422 \mathrm{~m}^{3} \mathrm{~m}^{-3}$ for pine area, being higher than the averages observed in the area under eucalyptus cultivation. The average values of Mi were higher than those recommended by Lima (2017) for an ideal soil for the development of plants, which is $0.330 \mathrm{~m}^{3} \mathrm{~m}^{-3}$.

Similar results for Mi were observed by Marques et al. (2012), which verified values of Mi ranging between 0.020 and $0.120 \mathrm{~m}^{3} \mathrm{~m}^{-3}$, in the depth of 0.00-0.40 m, in an Oxisol, in an area under forest in Amazon. The Mi of the soil is strongly influenced by the texture and by the organic carbon content, therefore, as the area of ciliary forest presents better structuring of the soil from the high amount of clay particles, this gives it a larger amount of Mi (Freitas et al., 2014).

It is observed that the BD1 was statistically lower in the ciliary forest, with an average of $1.340 \mathrm{~kg} \mathrm{dm}^{-3}$, compared to the BD1 obtained in the area with eucalyptus $\left(1.479 \mathrm{~kg} \mathrm{dm}^{-3}\right)$ and with pine $\left(1.571 \mathrm{~kg} \mathrm{dm}^{-3}\right)$ (Table 3). Similar results were observed by Silva et al. (2009), evaluating an Oxisol in the Cerrado, in areas cultivated for over 20 years with eucalyptus, pine and colliers (Sclerolobium paniculatum) and an adjacent area of native Cerrado, which obtained increases in the BD in eucalyptus and pine plantations. In general, BD2, BD3, and BD4 in the ciliary forest area were lower in relation to the area under cultivation of eucalyptus and the area under pine. 
Table 3. Attributes of an Oxisol (Haplic Acrustox), collected at depths of 0.00-0.10 m; 0.10-0.20 m; 0.20-0.30 m and $0.30-0.40 \mathrm{~m}$ under cultivation of eucalyptus, ciliary forest, and pine.

\begin{tabular}{|c|c|c|c|c|c|}
\hline \multirow{2}{*}{ Depths } & \multicolumn{3}{|c|}{ Average } & \multirow{2}{*}{$\mathrm{CV}$} & \multirow{2}{*}{ Calc. F } \\
\hline & Eucalyptus & Ciliary forest & Pine & & \\
\hline \multicolumn{6}{|l|}{$B D\left(\mathrm{~kg} \mathrm{dm}^{-3}\right)$} \\
\hline $0.00-0.10 \mathrm{~m}$ & $1.479 \mathrm{~b}$ & $1.340 \mathrm{c}$ & $1.571 \mathrm{a}$ & 6.17 & $41.571^{* *}$ \\
\hline $0.10-0.20 \mathrm{~m}$ & $1.519 \mathrm{a}$ & $1.343 \mathrm{~b}$ & $1.483 \mathrm{a}$ & 4.88 & $43.258^{* *}$ \\
\hline $0.20-0.30 \mathrm{~m}$ & $1.474 \mathrm{a}$ & $1.374 \mathrm{~b}$ & $1.452 \mathrm{a}$ & 5.49 & $10.949^{* *}$ \\
\hline $0.30-0.40 \mathrm{~m}$ & $1.408 \mathrm{a}$ & $1.314 \mathrm{~b}$ & $1.366 \mathrm{ab}$ & 5.78 & $9.106^{* *}$ \\
\hline \multicolumn{6}{|l|}{$G M\left(\mathrm{~kg} \mathrm{~kg}^{-1}\right)$} \\
\hline $0.00-0.10 \mathrm{~m}$ & $0.120 \mathrm{~b}$ & $0.155 \mathrm{a}$ & $0.100 \mathrm{c}$ & 13.67 & $63.001^{* *}$ \\
\hline $0.10-0.20 \mathrm{~m}$ & $0.115 b$ & $0.162 \mathrm{a}$ & $0.100 \mathrm{c}$ & 11.16 & $129.47^{* *}$ \\
\hline $0.20-0.30 \mathrm{~m}$ & $0.127 \mathrm{~b}$ & $0.170 \mathrm{a}$ & $0.110 \mathrm{c}$ & 9.46 & $140.16^{* *}$ \\
\hline $0.30-0.40 \mathrm{~m}$ & $0.131 \mathrm{~b}$ & $0.173 \mathrm{a}$ & $0.112 \mathrm{c}$ & 9.06 & $154.82^{* *}$ \\
\hline \multicolumn{6}{|l|}{$P R(M P a)$} \\
\hline $0.00-0.10 \mathrm{~m}$ & $4.694 \mathrm{a}$ & $2.575 \mathrm{~b}$ & $2.020 \mathrm{~b}$ & 48.52 & $22.041^{* *}$ \\
\hline $0.10-0.20 \mathrm{~m}$ & $6.200 \mathrm{a}$ & $4.397 \mathrm{~b}$ & $4.349 \mathrm{~b}$ & 41.11 & $6.633^{* *}$ \\
\hline $0.20-0.30 \mathrm{~m}$ & 5.127 & 4.986 & 5.615 & 38.05 & 0.685 \\
\hline $0.30-0.40 \mathrm{~m}$ & $4.323 \mathrm{~b}$ & $5.264 \mathrm{ab}$ & $6.010 \mathrm{a}$ & 27.23 & $8.924^{* *}$ \\
\hline \multicolumn{6}{|l|}{$V M\left(m^{3} m^{-3}\right)$} \\
\hline $0.00-0.10 \mathrm{~m}$ & $0.178 \mathrm{~b}$ & $0.207 \mathrm{a}$ & $0.157 \mathrm{c}$ & 14.43 & $23.401^{* *}$ \\
\hline $0.10-0.20 \mathrm{~m}$ & $0.175 \mathrm{~b}$ & $0.218 \mathrm{a}$ & $0.149 \mathrm{c}$ & 12.52 & $58.497^{* *}$ \\
\hline $0.20-0.30 \mathrm{~m}$ & $0.188 \mathrm{~b}$ & $0.233 \mathrm{a}$ & $0.161 \mathrm{c}$ & 10.13 & $87.206^{* *}$ \\
\hline $0.30-0.40 \mathrm{~m}$ & $0.184 \mathrm{~b}$ & $0.228 \mathrm{a}$ & $0.153 \mathrm{c}$ & 9.09 & $120.040^{* *}$ \\
\hline
\end{tabular}

Note. $\mathrm{BD}=$ bulk density; $\mathrm{GM}=$ gravimetric moisture; $\mathrm{PR}=$ soil resistance to penetration; $\mathrm{VM}=\mathrm{Volumetric}$ moisture. ${ }^{1}$ Averages followed by the same letter in the line do not differ statistically by the Tukey test. * Significant at $5 \%, * *$ Significant at $1 \%$.

The conditions under ciliary forest, the species that are being used differently in the dynamics of the root system, contributing to the low BD value observed in this area (Table 3). According to Steinbeiss et al. (2009), the low value of the $\mathrm{BD}$ is due to the high levels of organic carbon and of the intense biological activity (fauna and roots) that builds channels, cavities, and galleries. The increase of surface soil density in the areas of eucalyptus and pine may be related to the time of use of the area, to the root architecture, little soil cover during the initial plant growth period and to moisture conditions in the preparation and planting of seedlings (Costa et al., 2003).

The average values of soil GM presented differences by the F test, at $1 \%$ probability (Table 3 ). The ciliary forest presented values higher than the other evaluated areas, with GM1, GM2, GM3 and GM4 ranging from 0.155 to $0.173 \mathrm{~kg} \mathrm{~kg}^{-1}$, when compared to the area under eucalyptus $\left(0.115\right.$ to $\left.0.131 \mathrm{~kg} \mathrm{~kg}^{-1}\right)$, and the area under pine cultivation $\left(0.100\right.$ and $\left.0.112 \mathrm{~kg} \mathrm{~kg}^{-1}\right)$. The high GM value observed in the ciliary forest area may be associated with the higher concentration of pores responsible for soil water storage comparing to eucalyptus and pine areas. Thus, these results tend to be related to the higher water retention capacity at this local, which provides higher soil water content when it is in field capacity (Martinkoski et al., 2017). According to Reichert et al. (2007), soils in forest areas keep the soil moisture stable due to shading and accumulation of litter OM from trees.

For PR, the average of treatments presented differences when applying the F test at $1 \%$ probability (Table 3 ). The area under ciliary forest with PR1 and PR2 equal to $2.575 \mathrm{MPa}$ and 4.397 $\mathrm{MPa}$ and the area under pine with PR1 and PR2 equal to 2.020 and 4.349 MPa presented the lowest PR values when compared to eucalyptus (4.694 and 6.200 MPa). Cavenage et al. (1999), verified a similar behavior in eucalyptus area with higher PR values. In relation to the PR4, was observed the difference between the treatments, the area under cultivation of pine presented the highest value of PR4 $(6.010 \mathrm{MPa})$ compared to PR4 (4.323 MPa) in the eucalyptus area. It is probable that the natural soil densification and the low water content in the deeper layer caused an increase in the cohesion between the soil mineral particles, making them more difficult to be separated by external forces, resulting in the increase of the PR (Silveira et al., 2010; Soares et al., 2015). 
The VM averages among the evaluated areas presented differences by the $\mathrm{F}$ test at $1 \%$ of probability (Table 3 ). The VM1, VM2, VM3, and VM4 of the ciliary forest area were higher to those of the eucalyptus area and the area under pine cultivation. It is probable that the relationship between the low BD and the high Mi in the ciliary forest area contributed to the high VM levels found. In this sense, in relation to the low VM in the eucalyptus area, it may be associated with the Ma values that probably reduced the water availability in this area. These values, in the ciliary forest area, indicate a better morphology and architecture of the pores for water storage, influencing the rate of water infiltration of the soil, decreasing the surface flow and the production of sediments that contribute to the silting of watercourses, compromising its quality (Rodrigues et al., 2007).

\section{Conclusions}

The replacement of native vegetation by eucalypus and pinus forests, after 30 years of occupation, promoted differences between the physical attributes of the soil. Eucalyptus and pinus influenced the reduction of soil physical quality (lower total porosity and higher bulk density and resistance to penetration). While the reforested ciliary forest promoted ideal values of total porosity, microporosity and bulk density of soil.

\section{References}

Bonini, C. S. B., Alves, M. C., \& Montanari, R. (2015). Recuperação da estrutura de um Latossolo vermelho degradado utilizando lodo de esgoto. Revista Brasileira de Ciências Agrárias, 10, 34-42. https://doi.org/ 10.5039/agraria.v10i1a4513

Carter, M. R., \& Kunelius, H. T. (1986). Comparison of tillage and direct drilling for Italian ryegrass on the properties of a fine sandy loam soil. Canadian Journal of Soil Science, 66, 197-207. https://doi.org/ 10.4141 /cjss86-022

Cavenage, A., Moraes, M. L. T., Alves, M. C., Carvalho, M. A. C., Freitas, M. L. M., \& Buzetti, S. (1990). Alterações nas propriedades físicas de um Latossolo Vermelho-escuro sob diferentes culturas. Revista Brasileira de Ciência do Solo, 23, 997-1003. https://doi.org/10.1590/S0100-06831999000400027

Cordeiro, L. A. M., Vilela, L., Marchão, R. L., Kluthcouski, J., \& Júnior, G. B. M. (2015). Integração lavoura-pecuária e integração-pecuária-floresta: Estratégias para intensificação sustentável do uso do solo. Caderno de Ciência \& Tecnologia, 32, 15-43. Retrieved from https://seer.sct.embrapa.br/index.php/cct/ article/view/23294

Costa, F. S., Alburquerque, J. A., Bayer, C., Fontoura, S. M. V., \& Wobeto, C. (2003). Propriedades físicas de um Latossolo Bruno afetada pelos sistemas plantio direto e preparo convencional. Revista Brasileira de Ciência do Solo, 27, 527-535. https://doi.org/10.1590/S0100-06832003000300014

Embrapa (Empresa Brasileira de Pesquisa Agropecuária). (2014). Sistema brasileiro de classificação dos solos (4th ed., p. 376). Brasília, DF: Embrapa. Centro Nacional de Pesquisa de Solos.

Embrapa (Empresa Brasileira de Pesquisa Agropecuária). (2017). Manual de métodos de análise de solo (3rd ed., p. 575). Brasília, DF: Embrapa. Centro Nacional de Pesquisa de Solos.

Freitas, L., Casagrande, J. C., Oliveira, I. A., \& Campos, M. C. C. (2014). Análise multivariada na avaliação de atributos de solos com diferentes texturadiferentes texturas cultivados com cana-de-açúcar. Ciencias Agrárias, 57, 224-233. https://doi.org/10.4322/rca.ao1357

IBÁ (Indústria Brasileira de Árvores). (2017). Relatório anual da IBÁ 2017, ano base 2016. Retrieved February 9, 2018, from http://iba.org/images/shared/Biblioteca/IBA_RelatorioAnual2017.pdf

Juvenal, T. L. \& Mattos, R. L. G. (2002). O setor florestal no Brasil e a importância do reflorestamento. BNDES Setorial, 16, 3-30. Retrieved from http://web.bndes.gov.br/bib/jspui/handle/1408/1296

Kiehl, E. J. (1979). Manual de edafologia. São Paulo: Agronômica Ceres.

Libardi, P. L. (2005). Dinâmica da água no solo. São Paulo: EDUSP.

Lima, E. S., Lovera, L. H., Montanari, R., Panosso, A. R., \& Esteban, D. A. A. (2017). Relaciones entre componentes morfológicos de palmito y atributos físicos de un inceptisol: Una aproximación multivariada. Corpoica Ciencia y Tecnologia Agropecuaria, 18, 543-554. https://doi.org/10.21930/rcta.vol18_num $3 \_$art:743

Macdicken, K. (2015). Global Forest Resources Assessment 2015: How Are the World's Forests Changing? (2nd ed.). Roma, Italy: Food and Agriculture Organistation of the United Nations (FAO). Retrieved from http://www.fao.org/3/a-i4793e.pdf 
Marques, J. D. O., Luizão, F. J., Teixeira, W. G., \& Ferreira, S. J. F. (2012). Variações do carbono orgânico dissolvido e de atributos físicos do solo sob diferentes sistemas de uso da terra na Amazônia central. Revista Brasileira de Ciência do Solo, 36, 611-622. https://doi.org/10.1590/S0100-06832012000200030

Martinkoski, L., Vogel, G. F., Jadoski, S. O., \& Watzlawick, L. F. (2017). Qualidade física do solo sob manejo silvipastoril e floresta secundária. Floresta e Ambiente, 24, 1-9. https://doi.org/10.1590/2179-8087.028216

MEA (Millennium Ecosystem Assessment). (2005). Ecosystems and human well-being: Current state and trends. Washington, DC: World Resources Institute.

Melloni, R., Melloni, E. G. P., Alvarenga, M. I. N., \& Vieira, F. B. M. (2008). Avaliação da qualidade de solos sob diferentes coberturas florestais e de pastagem no sul de Minas Gerais. Revista Brasileira de Ciência do Solo, 32, 2461-2470. https://doi.org/10.1590/S0100-06832008000600023

R Core Team. (2014). R: A language and environment for statistical computing. Vienna: R Foundation for Statistical Computing.

Reichert, J. M., Suzuki, L. E. A. S., \& Reinert, D. J. (2007). Compactação de solo em sistemas agropecuários e florestais: identificação, efeitos limites críticos e mitigação. Tópicos de Ciência do Solo, 5, 49-134.

Ribeiro, K. D., Menezes, S. M., Mesquita, M. G. B. F., \& Sampaio, F. M. T. (2007). Propriedades físicas do solo, influenciadas pela distribuição de poros, de seis classes de solos da região de Lavras-MG. Ciência e Agrotecnologia, 31, 1167-1175. https://doi.org/10.1590/S1413-70542007000400033

Rodrigues, G. B., Maltoni, K. L., \& Cassiolato, A. M. R. (2007). Dinâmica da regeneração do subsolo de áreas degradadas dentro do bioma Cerrado. Revista Brasileira de Engenharia Agrícola e Ambiental, 11, 73-80. https://doi.org/10.1590/S1415-43662007000100010

Silva, A. M., Canuto, D. S. O., Moraes, M. L. T., \& Buzetti, S. (2012). Avaliação das propriedades químicas em solo de cerrado sob reflorestamento ciliar. Revista Floresta, 42, 49-58. https://doi.org/10.5380/rf. v42i1.26295

Silva, L. G., Mentes, I. C., Reis Junior, F. B., Fernandes, M. F., Melo, J. T., \& Kato, E. (2009). Atributos físicos, químicos e biológicos de um Latossolo de cerrado em plantio de espécies florestais. Pesquisa Agropecuária Brasileira, 44, 613-620. https://doi.org/10.1590/S0100-204X2009000600010

Silveira, D. C., Melo Filho, J. F., Sacramento, J. A. A. S., \& Silveira, E. C. P. (2010). Relação umidade versus resistência à penetração para um Argissolo Amarelo distrocoeso no Recôncavo da Bahia. Revista Brasileira de Ciência do Solo, 34, 659-667. https://doi.org/10.1590/S0100-06832010000300007

Soares, M. D. R., Campos, M. C. C., Rosa, Z. M., Brito, W. B. M., Franciscon, U., \& Castioni, G. A. F. (2015). Variabilidade espacial dos atributos físicos do solo em área de Terra Preta Arqueológica sob pastagem em Manicoré, AM. Ciencias Agrárias, 58, 434-441. https://doi.org/10.4322/rca.1975

Steinbeiss, S., Gleixner, G., \& Antonietti, M. (2009). Effect of biochar amendment on soil carbon balance and soil microbial activity. Soil Biology and Biochemistry, 41, 1301-1310. https://doi.org/10.1016/j.soilbio. 2009.03.016

Stolf, R., Murakami, J. H., Brugnaro, C., Silva, L. G., Silva, L. C. F., \& Margarido, L. A. C. (2014). Penetrômetro de impacto Stolf-programa computacional de dados em EXCEL-VBA. Revista Brasileira de Ciência do Solo, 38, 774-782. https://doi.org/10.1590/S0100-06832014000300009

Thomasson, A. J. (1978). Towards an objective classification of soil structure. Soil Science, 29, 38-46. https://doi.org/10.1111/j.1365-2389.1978.tb02029.x

van Lier, Q. J. (2010). Física do solo. Viçosa: SBCS.

\section{Copyrights}

Copyright for this article is retained by the author(s), with first publication rights granted to the journal.

This is an open-access article distributed under the terms and conditions of the Creative Commons Attribution license (http://creativecommons.org/licenses/by/4.0/). 